\title{
Wealth and Wealth Creation Capacities of Shariah-Compliant Firms: A Study on Impacts of Changes in Shariah-Compliant Status of Firms in Bursa Malaysia
}

\author{
Rabuan Mantine*1 and Mohamad Jais ${ }^{2}$ \\ ${ }^{1}$ School of Business and Management, University College of Technology Sarawak \\ ${ }^{2}$ Faculty of Economics and Business, Universiti Malaysia Sarawak \\ ${ }^{*}$ Corresponding author: rabuanm1@gmail.com
}

\begin{abstract}
Would shariah-compliant status change wealth and wealth creation capacities of a firm? In Bursa Malaysia about 80 percent of the listed firms have attained the shariah-compliant and placed in shariah-compliant index though a smaller number might subsequently lost the status and removed from the index every year. Judging from the percentage shariah-compliant status seems to be a 'must have' certificate for firms in Bursa Malaysia. The question is: does by attaining the shariah-compliant status a firm increase its wealth and wealth creation capacities, or on the contrary, by losing it a firm decrease its wealth creation capacities. This study therefore, investigates the influence of shariah-compliant status on the firms in Bursa Malaysia. Paired sample t-tests are employed on 400 selected firms in KLSI experiencing permanent change of shariah-compliant status from 1999 to 2010 period. It is found that firms would create more wealth or value upon attaining shariah-compliant status. Interestingly, the firms still maintain the same level of wealth even after losing the shariah-compliant status and excluded from the index. An implication for investors and fund managers is that, shariahcompliant status matters in investment decision.
\end{abstract}

Keywords: Islamic investment; Shariah-compliant index; Wealth creation

\section{Introduction}

The thrust of this study is premised on the notion that adherence to shariah laws by way of attaining shariah-compliant status have favorable impacts on the wealth creation capacities of the firms.

Previous studies analyzing the impacts of shariah rules on the wealth and wealth creation capacities of these modern investment vehicles compared shariah-compliant investments with their counterparts in conventional investments (Rahman \& Wajdi, 2006, Kraeussl \& Hayat, 2008, Lee \& Faff, 2009, Hong \& Kacperczyk, 2009). Others analyzing wealth in the context of the stocks' returns surrounding the events such as the announcement on the deletion and addition of stocks to the shariah index (Mat Nor et al., 2019) or market reactions on the stocks after the event (Yazi et al., 2015).

In wealth creation, it should be noted that the most challenging issue for a shariahcompliant firms is the prohibition of riba, maisir and gharar in financial transactions. What constitutes wealth creation in shariah-compliant firms must be free from those elements. Thus, firms certified as shariah-compliant would be subjected to the restriction of those prohibitions. For a firm, especially its corporate management, the question remains whether extra disclosure and the rigorous compliance requirements under Islamic index would undermine their performance and its capacity to sustain and create wealth (Hong \& Kacperczyk, 2009). This is a valid concern considering attaining shariah-compliant status would limit their financing 
alternative from interest bearing sources and deprive them of perhaps more profitable business ventures which are forbidden by shariah. On the contrary, however, the stringent shariahcompliant requirements may instill the right discipline to the corporate managements and eventually improve their financial performance and create wealth for the shareholders (Hakim \& Rashidian, 2004, Lee \& Faff, 2009).

Given these conflicting views, this study, therefore, attempts to verify the impacts of the shariah-compliant status to the wealth and wealth creation capacities of the firms in Bursa Malaysia under different market conditions focusing only on firms with changes in shariahcompliant status, as reflected by the firms' inclusion in or exclusion from the shariahcompliant index in Bursa Malaysia for the year 1999 until 2010, on firms' wealth and wealth creation capacities. Unlike previous studies, this study analyze the impacts of firms' compliance to shariah rules by comparing their pre- and post-shariah compliance performances or vice-versa. The wealth and the wealth creation capacity variables (discussed in the methodology later) would be tested on the same firms in order to effectively analyze the impacts of shariah certification or revocation on the firms' performance.

\section{Literature Review}

\section{Conceptual Clarifications on Wealth and Wealth Creation}

Wealth can be defined in several ways and never been a matter of general consensus. In Adam Smith's work (Smith, 1776), wealth is discussed in the context of a single nation which encompasses both private and public assets and goods in the beginning of industrial revolution. In technical economic term Enderle (2000) makes distinction between the private and public assets or goods in terms of its consumption characteristics. He defines public assets as nonrivalry and non-exclusive consumption whereas the private assets are the opposites.

Enderle (2000) further defines the creation of wealth as the production of public and private assets which involves the market and price mechanism. For an investment in a firm, wealth is primarily the stocks. Thus, the creation of wealth is measured in term of the increase in the value of stocks. Whereas, the creation of wealth in a nation, using the World Bank's "World Development indicators," is defined as the growth rates of the Gross Domestic Product (GDP).

Distribution of wealth is depicted by World Bank (2011) as the headcount ratio such as $\$ 1$ or $\$ 2$ a day which measures purchasing power parity between nations. Thus, correspondingly for a firm, we may add, the distribution of wealth is equivalent to the distribution of dividend for each stock.

The above literature links wealth creation to wealth distribution in a nation as well as in a firm. Further, for a nation, wealth creation and distribution is often inseparable to the noble objective of poverty eradication. Management literature on companies, on the other hand, assumes the firms' objective as "maximizing shareholder's value" thus negates the economic responsibilities of business organizations.

\section{Wealth in Islam}

All wealth is the possession of Allah with which humans are entrusted (Mansor, 2006). For that reason, the Holy Quran emphasizes the need to pursue one's share of wealth in this world which is clearly stated as a reminder in the following verse:

"But seek, with the (wealth) which Allah has bestowed on thee, the Home of the Hereafter, nor forget thy portion in this world: but do thou good, as Allah has been good to 
thee, and seek not (occasions for) mischief in the land: for Allah loves not those who do mischief."

(Surah Al-Qasas, 28:77)

Thus, it is a responsibility; it must be earned through permissible means and spent in permissible ways, such as spending on one's self and those for whom he is responsible for, without extravagance or waste. Wealth should be actively invested and should not be kept idle. Needless to say, the means of investment should also be allowed under Islamic law. It is also a duty under Islamic economic principle that wealth to be circulated so that it would not be confined amongst the rich. The most important mechanism for distribution of wealth in Islam is in the form of zakah where wealth generated are purified through zakah contribution which in turn distributed to the zakah beneficiaries such as the poor thus elevating the economic wellbeing of the Muslims (Shafi, 1968, Al-Qaradawi, 1999).

\section{Factors Influencing Firms' Wealth}

One way to measure the creation of wealth in a firm is by looking at the increase in the market value of its shares. This is particularly true as shares held by any shareholder is a representation of the level of wealth owned. Thus, appreciation of the share price in the capital market also leads to an increase in a shareholder's wealth. Conversely, a fall in the price of the shares held represents a loss of wealth of the shareholder (Ramakrishnan, 2010).

What factors could influence the wealth of a firm? In previous studies, corporate events such as the public announcement of sovereign fund investment (Dewenter et al. 2010), rights issues (Marsden, 2000), bonus issues and stock splits (Ray, 2011), ethical ratings (Fisher \& Khoury, 2006) could have an impact on firms wealth. According to Fama et al. (1969), corporate events either increase or decrease share prices of the firms concerned as the market adjusted to the newest available information.

Unfortunately, price alone could not gauge the wealth creation capacity of firms. Price manipulation created by the hypes surrounding certain corporate event may not genuinely reflect the wellbeing of the firms.

Thus, besides corporate events and dividend policy, the firms' wealth creation capacities are also attributed to the characteristics of the firms such as efficiency, quality management, corporate governance, business or investment decisions that would determine how firms perform in the long run. In the study on leverage and efficiency (Fiordelisi \& Molyneux, 2007) find that the shareholders' wealth is negatively correlated to cost and positively linked to firms' leverage. A choice of high yield and profitable investments is also important as suggested by Yahaya et al. (2009) in their study on the impacts of capital investment decision in high return projects. Similarly, Hendershoot (2004) finds that investment in innovation also contribute to wealth creation in firms. Studies on the deployment of corporate philanthropy (Godfrey, 2005; Carroll, 1979; Wood \& Logsdon, 2002) also show that the positive image created by the firms' corporate philanthropic activities contribute to the protection of shareholders' wealth.

\section{Mixed Results on the Performance of Shariah-compliant Firms}

Presently, there are two theories called 'Outperformance theory' and 'Underperformance theory' which are relevant in explaining the wealth and wealth creation capacities of shariahcompliant firms. Both theories provide the opposing arguments on the impacts of shariah compliance in Islamic funds, Islamic indices, Islamic screens and shariah-compliant firms which in general are called Islamic investing. 
Arguments for 'outperformance theory' suggest that responsible non-financial investment criteria inherent in the shariah law represents advanced risk management, hence limits the potential damage caused by the fund managers (Hakim \& Rashidian, 2004; Lee \& Faff, 2009) shariah compliance in Islamic investing also encourages firms to adopt corporate responsibility policy to put them in a better position to avoid any environmental and social crises that could lead to reputation damage, higher production costs, lost production, higher security costs and increased insurance premium. The lower debt ratio criteria in shariah screening process for example, excludes firms with speculative and risky behavior that lead to the volatility and uncertainty as witnessed over the course of 2008. Evidence to support this argument comes from the cases of Enron, Tyco and Worldcom. Before their scandals, these highly leveraged companies were excluded from the Dow Jones Islamic Market Index (Hussein, 2005). Shariah-compliant firms also use dividend as a signal to outsiders regarding private information about the firm's future earnings (Rahman \& Wajdi, 2006).

'Underperformance theory' on the other hand, holds that Islamic investing such as Islamic funds underperform conventional counterparts as a higher screening intensity reduces the performance of Islamic funds. The shariah-index screening unnecessarily limits one's potential universe of investments, thus dampening the benefits achieved by diversification. shariah-compliant screening also results in the exclusion of some standard 'sin' stocks (alcohol, gambling, tobacco) that deliver significantly positive abnormal returns and were among the world best performers even during recent global recession (Hong \& Kacperczyk, 2009). Besides, lower debt ratio criteria set-out in the shariah-compliant screening exposes Islamic investment to growth stocks than value stocks, as the former are considered to have a lower leverage than the latter (Campbell \& Vuolteenaho 2004). In addition, Islamic funds often have a higher cost of operation due to the extra research needed to identify investments besides the costs of hiring and maintaining a shariah board. While distraction by concerns about responsibility in Islamic investment would be detrimental for financial performance as it refuses to purely pursue profits (Geczy, Stambaugh \& Levin, 2005). Reasonably, Mueller (1991) called this underperformance theory as the "opportunity cost of discipleship," a theory which holds that adherents of moral or ethical systems that are different from the prevalent, mainstream social environment will face negative consequences as a result of their observance.

Both theories are derived from the analyses on shariah index against conventional index or shariah funds against conventional funds thus measuring the performance of the indexes and the fund managers rather than the impacts of shariah-compliant status on the firms. To analyze the impacts, this study, on the other hand, focuses on firm's performance by comparing its wealth creation capacities during pre- and post shariah-compliant periods.

\section{Methodology}

\section{Sample Data}

Firms experiencing shariah-compliant status changes are firms which are added to and deleted from the Kuala Lumpur Shariah Index (KLSI) since its inception in 1999. However, firms which were accorded shariah-compliant status in 1999 and remained in the shariah index since, for the duration limit of this study are not included in the samples. There are 693 additions and 186 deletions of firms to and from the KLSI between 1999 to 2010 periods.

Basically, the shariah-compliant status changes means a firm is categorized as shariahcompliant or shariah non-compliant for passing or failing shariah screening process and subsequently added to or deleted from Kuala Lumpur Shariah Index (KLSI). Firms that previously shariah non-compliant and later become shariah-compliant are grouped in sample- 
A, while firms which previously shariah-compliant and later become shariah non-compliant are grouped in sample-B which is summarized in the Table 1. Notice that the total sample size is very much reduced from the original number of firms added into and deleted form KLSI as the selected firms must fulfill the minimum requirement that at least one year of data are available to represent shariah-compliant period and shariah non-compliant period.

\section{Table 1 Sample A and Sample B: Changes in Shariah Compliance Status}

\begin{tabular}{ccc}
\hline Sample Type & Status Conversion & Number of Firms $(\boldsymbol{N})$ \\
\hline Sample A & from Shariah non-compliant to Shariah-compliant & 359 \\
Sample B & from Shariah-compliant to Shariah non-compliant & 41 \\
\hline
\end{tabular}

Source: Author

Additionally, this study also analyses the impacts of different market conditions on the wealth creation capacities of the firms. For this purpose, the data in sample-A and sample-B are further divided into two periods namely Period P1 (year 1999 to 2004) to represent market recovery period and Period P2 (year 2005 to 2010) for market stability period as in the Kuala Lumpur Composite Index (KLCI) (see Figure 1).

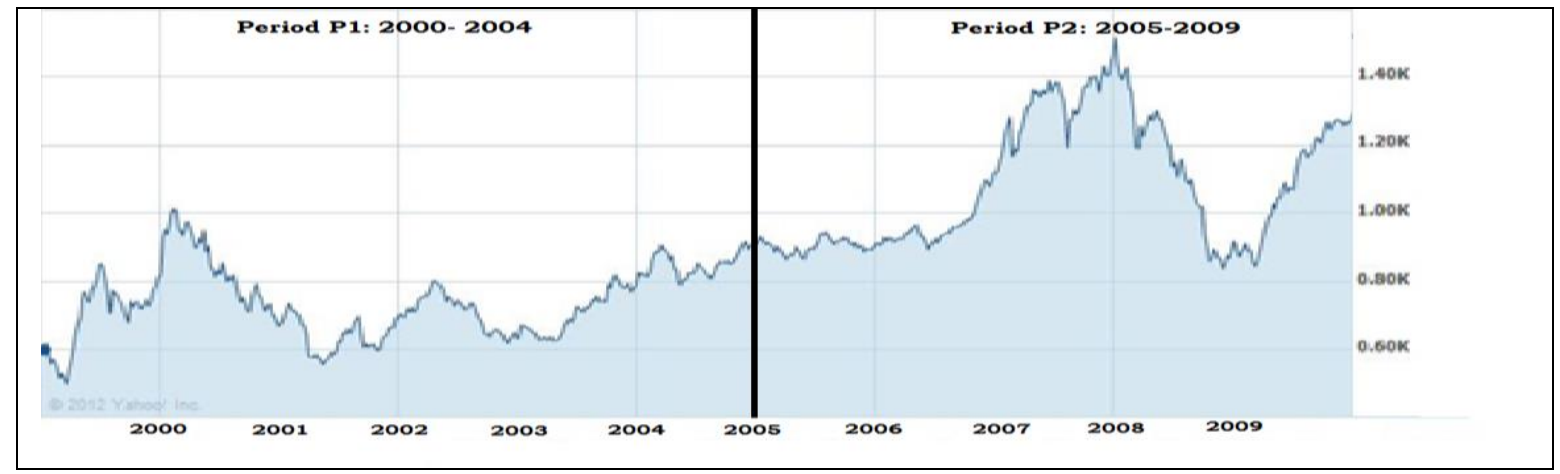

Figure 1: KLCI market performance

Source: Yahoo finance website (finance.yahoo.com)

For each firm in the sample, the accounting data are obtained for the minimum of one year and a maximum of three years surrounding the shariah-compliant status announcement year. The shariah-compliant status announcement itself is called "the event" and the year in which the announcement is made is considered "the event year". The years prior to the event and also years after the event are the two event windows denoted by $\mathrm{T} 1$ and $\mathrm{T} 2$ respectively. Year 0 , or the event year, is defined to be the fiscal year corresponding to the calendar year of the shariahcompliant status announcement made. For instance, if a shariah-compliant status announcement took place in calendar year 2004, then the event year or base year will be fiscal year 2004 regardless the announcements were made May or November in 2004. The event year, pre and post-event windows are illustrated in Figure 2. 


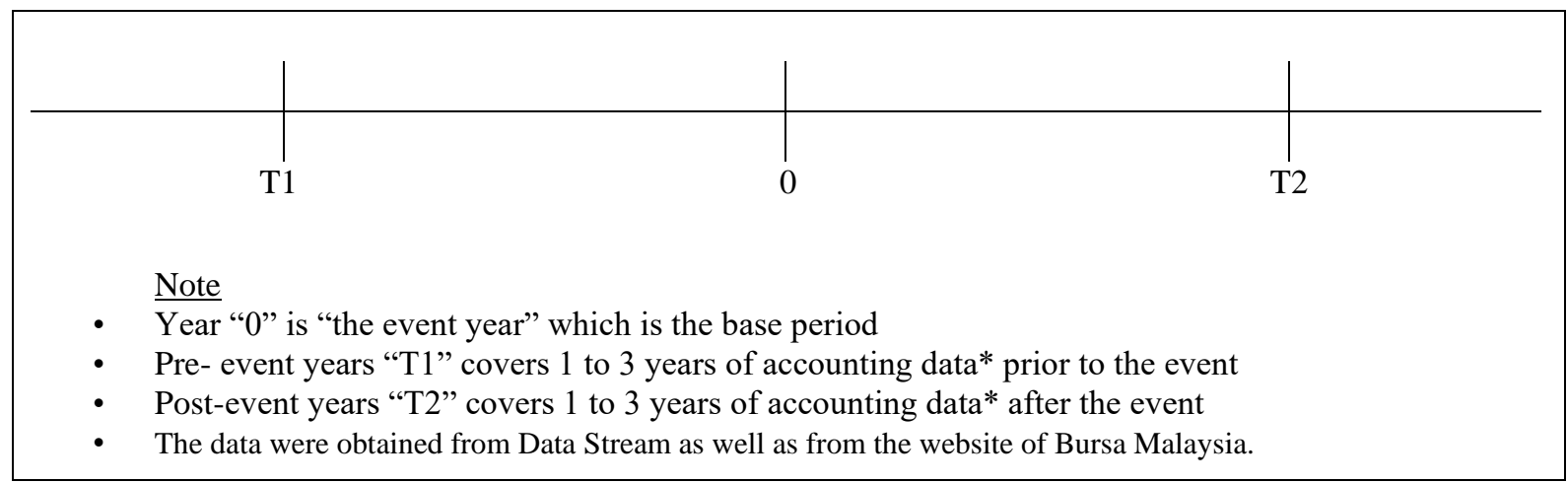

Figure 2: The Event and the Pre and Post-Event Windows

Source: Author

\section{Paired t-test}

This study employed paired t-test method on the five selected firms' variables representing measurements on wealth and wealth creation capacities. The paired sample t-test, sometimes called the dependent sample t-test, is a statistical procedure used to determine whether the mean difference between two sets of observations is zero. In a paired sample t-test, each subject or entity is measured twice, resulting in pairs of observations.

In this study the firms' wealth and the wealth creation capacities are measured by the firms' values and performances. The differences in the firms' values and performances as a result of changes in shariah-compliant status are analyzed by employing paired $t$-test on means of the selected variables comparing pre (or T1) and post (or T2) data on both Sample A and Sample B. Further analyses on the impact of different market conditions are performed by employing the same paired $t$-test on Sample A and Sample B which are now further segregated into Period P1 (market recovery period) and Period P2 (market stability period) respectively.

\section{Variables}

For this study, the wealth of a firm is represented by firm's value variables namely the market capitalization and the book-to-market ratio whereas the wealth creation capacity is represented by performance variables such as return on assets, debt-to-assets ratio and free cash flow. The variables used are shown in Table 2.

Table 2 Firms' Wealth and Performance Variables

\begin{tabular}{lll}
\hline $\begin{array}{c}\text { Variable } \\
\text { Abbreviations }\end{array}$ & Name and Formula & $\begin{array}{c}\text { Measurement on Wealth \& Wealth Creation } \\
\text { Capacities }\end{array}$ \\
\hline MktCap & $\begin{array}{l}\text { Market Capitalization } \\
\text { = Market price X No. of } \\
\text { Shares Outstanding }\end{array}$ & $\begin{array}{l}\text { Market capitalization shows size as well as value of } \\
\text { a firm as perceived by the market. Following Bichara } \\
(2008)\end{array}$ \\
\hline $\boldsymbol{B T M}$ & $\begin{array}{l}\text { Book-to-market ratio } \\
\text { Book Value of Firm }\end{array}$ & $\begin{array}{l}\text { Lower ratio (<1.0) denotes firm's equity is highly } \\
\text { valued by investors. Following Grullon and } \\
\text { Michaely (2004); Fenn and Liang (2001); and Smith } \\
\text { and Watts (1992) }\end{array}$ \\
\hline $\boldsymbol{R O A}$ & $\begin{array}{l}\text { Return on Asset } \\
\text { Opperating Income } \\
\text { Total Assets }\end{array}$ & $\begin{array}{l}\text { Higher ratio shows efficient management of firm's } \\
\text { assets to produce profits during a period. Following } \\
\text { Lyon and Barber (1996) }\end{array}$ \\
\hline
\end{tabular}




\begin{tabular}{lll}
\hline DebtAsset & $\begin{array}{l}\text { Debt-to-asset ratio } \\
=\text { Long Term Debt } \\
\text { Common Shares }\end{array}$ & $\begin{array}{l}\text { Higher ratio shows firm's high financial leverage } \\
\text { and risk. Similar to Wald (1999) }\end{array}$ \\
\hline $\boldsymbol{F C F}$ & $\begin{array}{l}\text { Free Cash Flow } \\
=\text { (Operating CashFlow) } \\
\text { - (Capital Expenditure) } \\
\text { - (Dividend Paid) }\end{array}$ & $\begin{array}{l}\text { High positive free cash flow indicates the firm's high } \\
\text { ability to support business but conditional on firms' } \\
\text { growth opportunities. Following Habib (2012). }\end{array}$ \\
\hline
\end{tabular}

Source: Author

\section{Results}

\section{Performance of Firms after Conversion to Shariah-Compliant Status}

In this analysis the t-test is applied to the firms in Sample A by comparing the performance after accorded shariah-complaint status as against performance before accorded shariahcompliant status.

As reflected and summarized in Table 3, the results of the analysis on firms' wealth and wealth creation capacities showed that, upon conversion to shariah-compliant status, the firms have grown in size and become more valuable in all market conditions in terms of market capitalization (MktCap). However, investors have shown no distinction on the firms' value per equity, before or after shariah-compliant status, in all market conditions, as reflected in the book-to-market ratio (BTM). Paradoxically, the conversion to shariah-compliant status seemed to negatively impact the efficiency in the firms' wealth creation capacities, in all market conditions, as shown in the return on assets ratio.

Table 3 Summary Results of Paired t-test for Sample A

\begin{tabular}{|c|c|c|c|c|}
\hline \multicolumn{5}{|c|}{$\begin{array}{c}\text { Shariah-Compliant Years } \\
\text { Minus (-) } \\
\text { Shariah Non-Compliant Years }\end{array}$} \\
\hline \multicolumn{2}{|c|}{$\begin{array}{c}\text { Performance Measured } \\
\text { \& Variables }\end{array}$} & $\begin{array}{l}\text { Overall Period } \\
(1999-\mathbf{2 0 1 0})\end{array}$ & $\begin{array}{c}\text { Market Recovery Period } \\
(1999-2004)\end{array}$ & $\begin{array}{l}\text { Market Stability Period } \\
\qquad(2005-2010)\end{array}$ \\
\hline \multirow{3}{*}{ Wealth } & MktCap & $\uparrow$ bigger size & $\uparrow$ bigger size & $\uparrow$ bigger size \\
\hline & & & & \\
\hline & BTM & $\Leftrightarrow$ No difference & $<=>$ No difference & $<=>$ No difference \\
\hline \multirow{3}{*}{$\begin{array}{l}\text { Wealth } \\
\text { Creation } \\
\text { Capacities }\end{array}$} & $\boldsymbol{R O A}$ & $\downarrow$ lower efficiency & $\downarrow$ lower efficiency & $\downarrow$ lower efficiency \\
\hline & DebtAsset & $\Leftrightarrow$ No difference & $<=>$ No difference & $<=>$ No difference \\
\hline & $F C F$ & $<=>$ No difference & $<=>$ No difference & $<=>$ No difference \\
\hline
\end{tabular}

Source: Author 
Table 3(a): Detailed Results of Paired $t$-test for Sample A

\begin{tabular}{|c|c|c|c|c|c|}
\hline \multirow[b]{3}{*}{ Variables } & \multicolumn{2}{|c|}{ Means } & \multicolumn{3}{|c|}{ Paired $t$-test for equality of means } \\
\hline & \multicolumn{2}{|c|}{$\begin{array}{c}\text { Shariah-Compliant Years } \\
\text { Minus (-) } \\
\text { Shariah Non-Compliant Years }\end{array}$} & \multirow[b]{2}{*}{ t- value } & \multirow[b]{2}{*}{$\begin{array}{c}\text { Sig. 2-Tailed } \\
\text { (p-value) }\end{array}$} & \multirow[b]{2}{*}{ Inference } \\
\hline & Mean & Std. Dev. & & & \\
\hline \multicolumn{6}{|c|}{ (Overall Period: 1999-2010) $(N=359)$} \\
\hline MktCap & 0.1909 & 0.4057 & $8.136^{* * *}$ & 0.000 & Reject $\mathrm{H}_{\mathrm{o}}$ \\
\hline BTM & -0.0796 & 1.6304 & -0.844 & 0.399 & Accept $\mathrm{H}_{\mathrm{o}}$ \\
\hline $\boldsymbol{R O A}$ & -0.0510 & 0.1131 & $-7.804^{* * *}$ & 0.000 & Reject $\mathrm{H}_{\mathrm{o}}$ \\
\hline DebtAsset & -0.0101 & 0.2444 & -0.717 & 0.474 & Accept $\mathrm{H}_{\mathrm{o}}$ \\
\hline $\boldsymbol{F C F}$ & 0.0000 & 0.0911 & -0.008 & 0.994 & Accept $\mathrm{H}_{\mathrm{o}}$ \\
\hline \multicolumn{6}{|c|}{ (Period-P1: 1999-2004) $(N=204)$} \\
\hline MktCap & 0.1849 & 0.4606 & $5.156^{* * *}$ & 0.000 & Reject $\mathrm{H}_{\mathrm{o}}$ \\
\hline BTM & -0.1674 & 1.9609 & -1.097 & 0.274 & Accept $\mathrm{H}_{\mathrm{o}}$ \\
\hline $\boldsymbol{R O A}$ & -0.0300 & 0.0678 & $-5.680^{* * *}$ & 0.000 & Reject $\mathrm{H}_{\mathrm{o}}$ \\
\hline DebtAsset & -0.0196 & 0.3171 & -0.795 & 0.428 & Accept $\mathrm{H}_{\mathrm{o}}$ \\
\hline$F C F$ & -0.0084 & 0.0996 & -1.090 & 0.277 & Accept $\mathrm{H}_{\mathrm{o}}$ \\
\hline \multicolumn{6}{|c|}{ (Period-P2: 2005-2010) $(N=155)$} \\
\hline MktCap & 0.1983 & 0.3271 & $7.017^{* * *}$ & 0.000 & Reject $\mathrm{H}_{\mathrm{o}}$ \\
\hline BTM & 0.0286 & 1.0924 & 0.303 & 0.762 & Accept $\mathrm{H}_{\mathrm{o}}$ \\
\hline $\boldsymbol{R O A}$ & -0.0769 & 0.1475 & $-6.040^{* * *}$ & 0.000 & Reject $\mathrm{H}_{\mathrm{o}}$ \\
\hline DebtAsset & 0.0016 & 0.0980 & 0.184 & 0.855 & Accept $H_{o}$ \\
\hline$F C F$ & 0.0103 & 0.0785 & 1.519 & 0.131 & Accept $\mathrm{H}_{\mathrm{o}}$ \\
\hline
\end{tabular}

Note: ${ }^{* * *},{ }^{* *},{ }^{*}$ denote significant at $1 \%, 5 \%$, and $10 \%$ level respectively. However, only $p$-value $\leq 5 \%$ is accepted for this test.

Source: Author

The results of the analysis as per details in Table 3(a) show that the market capitalizations ( $\mathrm{MktCap}$ ) for firms in Sample A are significantly different, indicating positive influence of shariah-compliant status during overall period (Period: 1999-2010), recovery period (Period-P1: 1999-2004) and stability period (Period-P2: 2005-2010) registering differences in means of $0.1909,0.1849$ and 0.1983 respectively at $5 \%$ significant level.

Oddly, at the same time, the negative influence of shariah-compliant status on the return-on-asset $(R O A)$ for firms in Sample A are also registered during the overall period (Period: 1999-2010), recovery period (Period-P1: 1999-2004) and stability period (Period-P2: 2005-2010) registering difference in means of $-0.0510,-0.03000$ and -0.0769 respectively at $5 \%$ significant level.

Meanwhile, observations on the results of four other variables namely, book-to-market $(B T M)$, debt-to-asset (DebtAsset) and free cash flow $(F C F)$, show that there are no influence of shariah-compliant status as no significant difference registered in means in all market conditions. 


\section{Performance of Firms after Losing Shariah-compliant status}

Similar independent $t$-test also applied to firms in Sample B. In terms of shariah-compliant status, firms in Sample B are the opposite of Sample A. Unlike Sample A, firms in Sample B started as shariah-compliant firms and then later withdrawn from the shariah-compliant status listing and become shariah non-compliant.

The results of the analysis on Sample B as summarized in Table 4 showed that, the firms' prior performance under shariah-compliant status are no different than the performance after losing shariah-compliant status with the exception of the firms' performance during market stability period. During the period, investors perceive the firms' equity as more valuable (proxied by BTM) when the firms still have shariah-compliant status as compared to after losing shariah-compliant status. However, during the same period, the opposite is true for the firms' free cash flow as the firms registered lower free cash flow $(F C F)$ when the firms still have shariah-compliant status as compared to after losing shariah-compliant status.

The paired $t$-tests as detailed out in Table 4(a) showed that the differences in means in all five variables are insignificant in the overall period (Year 1999-2010). When broken down into the two periods namely recovery and stability periods these results seemed to be consistent during recovery period (Period P1: Year 1999- 2004) but not during stability period (Period P2: 2005-2010). During the market stability period (Period P2: Year 2005- 2010), the book-tomarket $(B T M)$ and free cash flow (FCF) variables registered differences in means of -3.005 and $\quad-2.189$ respectively, significant at $5 \%$ level.

Table 4 Summary Results of Paired $t$-test for Sample B

\begin{tabular}{|c|c|c|c|c|}
\hline \multicolumn{5}{|c|}{$\begin{array}{c}\text { Shariah-Compliant Years } \\
\text { Minus (-) } \\
\text { Shariah Non-Compliant Years }\end{array}$} \\
\hline \multicolumn{2}{|c|}{$\begin{array}{c}\text { Performance Measured } \\
\text { \& Variables }\end{array}$} & $\begin{array}{l}\text { Overall Period } \\
(1999-2010)\end{array}$ & $\begin{array}{c}\text { Market Recovery Period } \\
(1999-2004)\end{array}$ & $\begin{array}{c}\text { Market Stability Period } \\
(2005-2010)\end{array}$ \\
\hline & MktCap & $\Leftrightarrow$ No difference & $\Leftrightarrow>$ No difference & $\Leftrightarrow>$ No difference \\
\hline \multicolumn{5}{|l|}{ Wealth } \\
\hline & BTM & $\Leftrightarrow$ No difference & $\Leftrightarrow>$ No difference & $\uparrow$ higher value \\
\hline & $R O A$ & $\Leftrightarrow>$ No difference & $\Leftrightarrow>$ No difference & $<=>$ No difference \\
\hline \multirow{2}{*}{$\begin{array}{l}\text { Wealth } \\
\text { Creation } \\
\text { Capacities }\end{array}$} & DebtAsset & $\Leftrightarrow$ No difference & $\Leftrightarrow$ No difference & $\Leftrightarrow$ No difference \\
\hline & $F C F$ & $\Leftrightarrow$ No difference & $\Leftrightarrow>$ No difference & $\downarrow$ lower cash flow \\
\hline
\end{tabular}

Source: Author 
Table 4(a) Detailed Results of Paired $t$-test for Sample B

\begin{tabular}{|c|c|c|c|c|c|}
\hline \multirow[b]{3}{*}{ Variables } & \multirow{2}{*}{\multicolumn{2}{|c|}{$\begin{array}{l}\text { Means } \\
\text { Shariah-Compliant Years } \\
\text { Minus (-) } \\
\text { Shariah Non-Compliant Years }\end{array}$}} & \multicolumn{3}{|c|}{ Paired $t$-test for equality of means } \\
\hline & & & \multirow[b]{2}{*}{ t- value } & \multirow[b]{2}{*}{$\begin{array}{c}\text { Sig. 2-Tailed } \\
\text { (p-value) }\end{array}$} & \multirow[b]{2}{*}{ Inference } \\
\hline & Mean & Std. Dev. & & & \\
\hline \multicolumn{6}{|c|}{ (Overall Period) $(N=41)$} \\
\hline MktCap & 0.0019 & 0.1620 & 0.063 & 0.950 & Accept $\mathrm{H}_{\mathrm{o}}$ \\
\hline BTM & -0.0639 & 1.0801 & -0.324 & 0.748 & Accept $\mathrm{H}_{\mathrm{o}}$ \\
\hline$R O A$ & -0.0023 & 0.0279 & -0.459 & 0.649 & Accept $\mathrm{H}_{\mathrm{o}}$ \\
\hline DebtAsset & -0.1593 & 0.7349 & -1.187 & 0.245 & Accept $\mathrm{H}_{\mathrm{o}}$ \\
\hline$F C F$ & -0.0191 & 0.0528 & $-1.979^{*}$ & 0.057 & Accept $\mathrm{H}_{\mathrm{o}}$ \\
\hline \multicolumn{6}{|c|}{ (Period-P1: 1999-2004) $(N=17)$} \\
\hline MktCap & 0.0143 & 0.1329 & 0.388 & 0.705 & Accept $\mathrm{H}_{\mathrm{o}}$ \\
\hline BTM & 0.5001 & 1.2633 & 1.427 & 0.179 & Accept $\mathrm{H}_{\mathrm{o}}$ \\
\hline$R O A$ & -0.0054 & 0.0373 & -0.517 & 0.614 & Accept $\mathrm{H}_{\mathrm{o}}$ \\
\hline DebtAsset & -0.4671 & 1.0510 & -1.603 & 0.135 & Accept $\mathrm{H}_{\mathrm{o}}$ \\
\hline$F C F$ & -0.0146 & 0.0656 & -0.802 & 0.438 & Accept $\mathrm{H}_{\mathrm{o}}$ \\
\hline \multicolumn{6}{|c|}{ (Period-P2: 2005-2010) $(N=24)$} \\
\hline MktCap & -0.0076 & 0.1846 & -0.171 & 0.867 & Accept $\mathrm{H}_{\mathrm{o}}$ \\
\hline BTM & -0.4951 & 0.6794 & $-3.005^{* * *}$ & 0.008 & Reject $\mathrm{H}_{\mathrm{o}}$ \\
\hline $\boldsymbol{R O A}$ & 0.0000 & 0.0188 & -0.008 & 0.994 & Accept $\mathrm{H}_{\mathrm{o}}$ \\
\hline DebtAsset & 0.0762 & 0.1206 & 2.604 & 0.019 & Accept $\mathrm{H}_{\mathrm{o}}$ \\
\hline$F C F$ & -0.0225 & 0.0424 & $-2.189^{* *}$ & 0.044 & Reject $\mathrm{H}_{\mathrm{o}}$ \\
\hline
\end{tabular}

Note: ${ }^{* * *}$ significant at $1 \%$ level, ${ }^{* *}$ significant at $5 \%$ level, and ${ }^{*}$ significant at $10 \%$ level. However, only $p$ value $\leq 5 \%$ is accepted for this test.

Source: Author

\section{Discussions}

The results of the study on the impacts of certification of shariah-compliant status to the firms (Firms in Sample A) showed investors' perception on the value of the firms is indifferent, before or after the firms were awarded or certified the shariah-compliant status, as reflected by the book-to-market ratio (BTM) which is not significantly different before or after accorded shariah-compliant status. Thus, the registered significant increase in the market capitalization (MktCap) of the firms is merely indicating the firms are growing in size rather than the increase in investors' or market valuation on the equity. Instead, the certification of shariah-compliant status also seemed to reduce the internal efficiency on the asset utilization as recorded by the lower return to assets ratio $(R O A)$ of the firms.

The results of study on the impacts of the withdrawal of the shariah-compliant status from the firms (firms in Sample B) also indicates no influence on the wealth as well as wealth creation capacities of the firms. However, upon further analysis under different market conditions, the significant different could be observed during market stability period where the value of the firms, as reflected in the book-to-market (BTM) ratio, is perceived as lower by investors after the firms' shariah-compliant status were withdrawn. On the other hand, also 
during market stability period, the withdrawal of the shariah-compliant status, increase the free cash flow $(F C F)$ of the firm.

However, when analyzed as a whole, the results from Sample A and Sample B expose the three missing pieces of the jigsaw puzzle. First, firms became less efficient in asset utilization (proxied by ROA) immediately after attaining shariah compliant status (in Sample A), while no loss in efficiency is found among firms even after losing shariah-compliant status (in Sample B). Second, the remarkable growth of wealth (proxied by MktCap) in firms after attaining shariah compliant status (in Sample A), while no loss in value of firms despite losing shariah-compliant status (in Sample B). Third, investor' perception on the value of the firms (proxied by BTM) is not influenced by shariah-compliant status irrespective of whether the firms were newly certified with shariah-compliant status or withdrawn shariah-compliant status.

The overall analysis thus, point to the different attributes of Sample A and Sample B. Sample A comprises firms which are relatively younger than firms in Sample B as they are newly listed in the Stock Exchange. The firms are therefore at the early stage of their life cycles or growth stage as compared to firms in Sample B which are at the maturity stage and perceived as having no significant growth prospect (proxied by BTM) and declining investment trend (proxied by $F C F$ ). It should be noted that firms having shariah-compliant status would have been subjected to rigorous shariah disciplines in financing and also in business activities. The loss in efficiency is by some means expected as the firms make necessary adjustments to the shariah rules. However, over time, the early painful start is compensated and efficiency would no longer become an issue as shown by firms in Sample B. Observation on investors' perception on the value per equity (as proxied by BTM) of the more mature firms in Sample B especially during market stability period, indicates that they make no distinction based on shariah compliance status but rather, make valuation based on the attribute of the firms. Coincidently, firms in Sample B, considerably no longer in the growth stage are valued more during the shariah-compliant years than after losing shariah-compliant status, which is consistent with the evolvement of their life cycles towards maturity stage where further investment opportunities become limited (as proxied by $F C F$ ) as proposed by Muller (1972).

\section{Limitations}

This study only covers the period of about ten years since the inception of Islamic index in Bursa Malaysia in 1999. Future study covering longer time horizons is recommended as the Islamic Index becomes more mature and developed. Thus, it should be cautioned that the results of the study may not representative of situations in other Islamic indices or screens.

\section{Conclusions}

The findings are therefore support the outperformance theory of the previous researchers (Hakim \& Rashidian, 2004; Lee \& Faff, 2009) on the positive impact of shariah compliance. After accorded the shariah-compliant status, the wealth creation is observed where firms have healthily grown in size by raising as much capital as they required from the stock market and become more valuable after being included in the Islamic index. The firms still maintain their wealth creation capacities in the firms' performance, perhaps due to years of shariah-compliant discipline exposure, even after being excluded from the Islamic index. The impact of shariah compliance is further magnified during market stability period where the firms were valued 
more by investors during shariah-compliant years compared to after the annulment of the shariah-compliant status.

Although generally investors seemed unconcerned on shariah-compliant status as they value firms based on performance rather than the shariah-compliant certification, the findings indicate that Islamic investors who are more assiduous in their investment choices may not necessarily have to pay an opportunity cost for adhering to their faith as suggested by Mueller (1991). The steady and healthy growth of the firms after accorded shariah-compliant status has compensated the initial set back in terms of efficiency which may have been caused by the necessary adjustments to financing and business practices in accordance to shariah requirements.

Therefore, the inception of Islamic index in Bursa Malaysia is indeed commendable and duly rewarded judging by its performance. The stringent shariah screening imposed on firms for inclusion in the index encourages improvement of firms' fundamentals and rewards corporate responsibility. Shariah-compliant firms can offer long term wealth appreciation. The avoidance of the three forbidden elements, riba, gharar and maisir helps firms to chart real economic and financial objectives without over exposure to the risks of financial leverage, uncertainties and speculations.

\section{References}

Al-Qaradawi, Yusuf (1999). Fiqh az-Zakah- A Comparative Study, London: Dar al-Taqwa Ltd.

Bichara, Z. (2008). Institutional ownership and dividend policy: A framework based on tax clientele, information signalling and agency costs. Theses and Dissertation paper. UNT Libraries. Retrieved from http:// digital.library.unt. edu/ ark: /67531/ metadc9004/

Campbell, J.Y. \& Vuolteenaho, T. (2004). Bad Beta, Good Beta. American Economic Review, 94(5), 249-1275.

Carroll, A.B. (1979). A Three Dimensional Model of Corporate Performance. Academy of Management Review, 4, 497-505.

Dewenter, Kathryn L., Xi Han., \& Malatesta, Paul, H. (2010). Firm Values and Sovereign Wealth Fund Investments. Journal of Financial Economics, 98, 256-278

Enderle, G. (2000). Whose Ethos for Public Goods in a Global Economy? An Exploration in International Business Ethics. Business Ethics Quarterly, 10(1), 131-44.

Fama, E.F., Jensen L.M., \& Roll, R. (1969). The Adjustment of Stock Prices to New Information. International Economic Review, 10 (1), 1-21.

Fenn, G. \& Liang, N. (2001). Corporate Payout Policy and Managerial Stock Incentives. Journal of Financial Economics, 60, 45-72

Fiordelisi, F. \& Molyneu, P. (2007). The Determinants of Shareholder Value in European Banking. Journal of Banking \& Finance, 34 (6), 1189-1200

Fischer, K. \& Khoury, N. (2006). The Impact of Ethical Ratings on Canadian Security Performance: Portfolio Management and Corporate Governance Implications. The Quarterly Review of Economics and Finance, 47 (2007), 40-54

Geczy, C.C., Stambaugh, R.F., \& Levin, D. (2005). Investing On Socially Responsible Mutual Funds. Working Paper, the Rodney L. White Center of Financial Research, the Wharton School, University of Pennsylvania. Retrieved from: http://papers.ssrn.com/sol3/ papers.cfm?abstract_id $=416380$ 
Godfrey, Paul C. (2005). The Relationship between Corporate Philanthropy and Shareholder Wealth: A Risk Management Perspective. Academy of Management Review, 30(4), 777-798.

Grullon, G. \& Michaely, R. (2004). The Information Content of Share Repurchase Programs. Journal of Finance, 59(2), 651-680.

Habib, Ahsan. (2012). Growth Opportunities, Earnings Permanence and the Valuation of Free Cash Flow, Australasian Accounting, Business and Finance Journal, 5(4), 2011, 101-122.

Hakim, S. \& Rashidian, M. (2002). Risk \& Return of Islamic Stock Market Indexes. Conference paper presented at Economic Research Forum Annual Meeting Sharjah UAE October 26th. Retrieved from: http://www.lariba.com/knowledgecenter/articles/index.htm

Hendershott, Robert J. (2004). Net Value: Wealth Creation (And Destruction) During the Internet Boom. Journal of Corporate Finance, 10, 281- 299

Hong, H. \& Kacperczyk, M. (2009). The Price of Sin: The Effects of Social Norms on Markets. Journal of Financial Economics, 93(1), 15-36.

Hussein, Khaled A. (2005). Islamic Investment: Evidence from Dow Jones and FTSE Indices. Working paper, Islamic Business Research Centre, Norway.

Kraeussl, R. \& Hayat, R. (2008). The Performance of Islamic Equity Funds. Working Paper, Vrije University Amsterdam. Retrieved from http://papers.ssrn.com/sol3/ papers.cfm? abstract_id=1320712

Lee, D.D. \& Faff, R.W. (2009). Corporate Sustainability Performance and Idiosyncratic Risk: A Global Perspective. The Financial Review, 44, 213-237.

Lyon, J. \& Barber, B. (1996). Detecting abnormal operating performance: The empirical power and specification of test statistics. Journal of Financial Economics, 41, 359-99.

Mansor, Fadillah (2006). Wealth Creation and Wealth Generation: Analysis from Quraanic Perspective. Conference paper: National Seminar in Islamic Banking \& Finance, August 29-30, 2006, Kuala Lumpur, Malaysia. (Unpublished). Retrieved from: http://eprints.um.edu.my/927/

Marsden, Alastair (2000). Shareholder Wealth Effects Of Rights Issues: Evidence From The New Zealand Capital Market. Pacific-Basin Finance Journal, 8, 419-442

Mat Nor, F., Shaharuddin, A., Marzuki, A., \& Ramli, N.A. (2019). Revised Malaysian Shariah Screening: It's Impact on Islamic Capital Market. Research in World Economy, 10(1).

Mueller, D.C. (1972). A life cycle theory of the firm. Journal of Industrial Economics, 20(3), 199-219.

Mueller, Samuel A. (1991). The Opportunity Cost of Discipleship: Ethical Mutual Funds and Their Returns. Sociological Analysis, 52, 111-124.

Rahman, F.A. \& Wajdi, F.M. (2006). Dividend Signaling Hypothesis and Agency Cost: An Investigation on Shariah and Non-Shariah Compliant Firms in Kuala Lumpur Shariah Index. Empirika, 19(1): 1-9.

Ramakrishnan, K. (2010). Redistribution of Wealth on Merger Announcements in India. Management Research Review, 33(8), 798-810

Ray, Koustubh Kanti (2011). Market Reaction to Bonus Issues and Stock Splits in India: An Empirical Study. The IUP Journal of Applied Finance, 17(1), 54-69 
Shafi, Mufti Muhammad (1968). Distribution of Wealth in Islam. Conference Paper Read at the International Islâmic Conference, Rawalpindi, Pakistan on February 13, 1968 (Muhammad Hasan Askari/Karrar Husain, Tran). Retrieved from http://ccminc.org/oldsite/iqra/articles/distrw/index.html

Smith, A. (1776). An Inquiry Into the Nature and Causes of the Wealth of Nations, Edited by R.H. Campbell, A.S. Skinner, W.B. Todd. Oxford: Clarendon Press.

Smith, C.W. \& Watts R.L. (1992). The Investment Opportunity Set and Corporate Financing, Dividend, and Compensation Policies. Journal of Financial Economics, 32, 263292

Wood, D.J. \& Logsdon, J.M. (2002). Business Citizenship: From Individuals to Organizations. Business Ethics Quarterly, 12: 59-94.

World Bank (2011). Gross Domestic Product 2010, PPP. World Development Indicators Database. Retrieved on July 1. Retrieved from database, http: // siteresources. worldbank.org /DATASTATISTICS/Resources/ GDP_PPP.pdf)

Yahaya, N.H., Kila, S.M., \& Mahmood, W.M. (2009). Adopting Economic Value Added (EVA) on Real Estate Corporations in Malaysia. MPRA Paper, No. 14602 (Retrieved from: http://mpra.ub.uni-muenchen.de/)

Yazi, E., Morni, F., \& Imm, S.S. (2015). The Effects of Shariah Compliance Announcement towards Stock Prices Changes in Malaysia. Journal of Economics, Business and Management, 3(11), 1019-1023. 